Article No 231

DOI: https://doi.org/10.26881/srg.2020.7.06

Citation:

Dąbrowska, M. (2020). The Nineteenth-century Dictionaries

of Russian Women Writers: (not Only) General Bibliographical

and Literary Historical Principles. Studia Rossica Gedanensia, 7: 73-87.

DOI: https://doi.org/10.26881/srg.2020.7.06

\title{
THE NINETEENTH-CENTURY DICTIONARIES OF RUSSIAN WOMEN WRITERS: (NOT ONLY) GENERAL BIBLIOGRAPHICAL AND LITERARY HISTORICAL PRINCIPLES
}

\author{
MAGDALENA DĄBROWSKA \\ Uniwersytet Warszawski / University of Warsaw \\ Wydział Lingwistyki Stosowanej / Faculty of Applied Linguistics \\ Katedra Rusycystyki / Institute of Russian Studies \\ ul. Krakowskie Przedmieście 26/28, 00-927 Warszawa, Polska / \\ Krakowskie Przedmieście st. 26/28, 00-927 Warsaw, Poland \\ E-mail: m.dabrowska@uw.edu.pl \\ ORCID: https://orcid.org/0000-0002-4014-4725 \\ (Nadesłano / Received 30.09.2020. Zaakceptowano / Accepted 7.10.2020)
}

\begin{abstract}
The article presents the oldest dictionaries of the Russian women writers (bibliographical data and literary historical context): 1. Bibliographical Catalogue of the Russian Women Writers (1826) by Stepan Russov; 2. Materials to the History of the Russian Women Writers by Mikhail Makarov (published in the periodical "Damskij zhurnal" 1830, 1833); 3. Bibliographical Dictionary of the Russian Women Writers (1889) by Nikolai Golitsyn; 4. Our female writers. The dictionary of the Russian women writers (1891) by Stepan Ponomaryov. The first dictionary of the Russian writers (Nikolai Novikov, 1772) serves as the interpretative context. The structure and contents of the dictionaries are discussed.
\end{abstract}


Key words: woman writers, Russia, dictionary, Stepan Russov, Mikhail Makarov, Nikolai Golitsyn, Stepan Ponomaryov

\section{Abstrakt \\ Dziewiętnastowieczne słowniki pisarek rosyjskich: (nie tylko) generalia bibliograficzno-historycznoliterackie}

Artykuł przedstawia najstarsze słowniki pisarek rosyjskich (dane bibliograficzne i kontekst historycznoliteracki): 1. Katalog bibliograficzny rosyjskich pisarek (1826) Stiepana Russowa, 2. Materialy do historii rosyjskich kobiet autorów Michaiła Makarowa (opublikowane w czasopiśmie „Damskij żurnal” w latach 1830 i 1833), 3. Słownik bibliograficzny pisarek rosyjskich (1889) Nikołaja Golicyna, 4. Nasze pisarki. Słownik bibliograficzny pisarek rosyjskich (1891) Stiepana Ponomariowa. Kontekst interpretacyjny stanowi pierwszy rosyjski słownik pisarzy (Nikołaja Nowikowa, 1772). Przedmiotem rozpatrzenia jest struktura i zawartość słowników.

Słowa kluczowe: pisarki, Rosja, słownik, Stiepan Russow, Michaił Makarow, Nikołaj Golicyn, Stiepan Ponomariow

For centuries, the general perception of woman was that of a muse and a consumer of literature rather than a creator of it. The memory of Sappho, one of the most prominent women in Rapahel's Parnassus, did little to change this. Magdalena Goik perceives the explanation for this state of affairs in the historical durability of the hierarchical paradigm and from the constitution of the artist herself, whose "most salient internal trait (...) apart from creativity and technical excellence would seem to be an authenticity emanating from self-awareness," and while "this authenticity can be seen in every artist, regardless of sex," Magdalena Goik cites Erica Jong's observation that nevertheless "it is harder for a woman to become an artist, because it is harder for her to become herself." (Goik 2010: 8). "In order to achieve the necessary selfawareness," Magdalena Goik concludes, "a woman must transcend stereotypical social roles that come with what is essentially an instruction manual for behaviour." (Goik 2010: 8). This article aims to shed light on the times and the phenomena that indicate women's transition in the field of literature 'from invisibility to agency'. (cf. Bałżewska, Korczyńska-Partyka, Wódkowska 2015). It simultaneously poses a question that casts doubt on this emerging 'agency:' were the literary creations of women perceived at the time as a full-fledged component of the literary historical process, or merely as an interesting 'appurtenance' to it?

The formation of writers' dictionaries - similarly to literary historical syntheses constitutes an expression of the drive to capture in one place the totality of knowledge of literary history. While syntheses are tasked with painting a picture of the laws of the literary historical process, writers' dictionaries are prepared with a view to presenting the life and work of its creators, generally listed in alphabetical or chronological-al- 
phabetical order (see Głowiński 2010: 513, Sławiński 2010: 553). Writers’ dictionaries can be divided into biographical and biobibliographical. The former are composed of writers' biographies and outlines of their work; in the latter, biographical profiles are enriched with bibliographical addresses of works by the writers and scholarly writings about them (their addresses may be included in a biographical note, or may compose a separate entry located underneath). As this shows, writers' dictionaries are relevant not only to the interests of literary historians, but also bibliographers (bibliography constitutes a separate discipline in the science of books, while it is a supplementary science to the history of literature, and in fact among the primary ones). Writers' dictionaries - considering how they shed light on more than one artist - can be considered examples of polybiobibliographical works; their individual entries - devoted to a single individual - are monobiobibliographical (Levin, Teplickaâ 2015: 7). The earliest attempts at a synthetic framing of literature came about in Antiquity, such as Tables of Those Who Have Distinguished Themselves in All Areas if Literature, and What They Wrote (Pinakes) by Callimachus, a poet and scholar of the Alexandrian Library (see Smolarczyk-Rostropowicz 1990: 266).

Of far greater importance than the categorisation presented above is the distinction between general and specialist dictionaries. In Russia, general dictionaries were the first to come about, compiling knowledge about all creators of national literature both past and present. The earliest is considered to be An Attempt at a Historical Dictionary of Russian Writers (Опьт исторического словаря о российских писателях) from 1772 by Nikolai Novikov (see Martynov 1968: 184-191, Lepehin 1989: 234-250), a leading figure in the publishing and bookselling world of Enlightenment Russia; however, we should also keep in mind the anonymous Information on Some Russian Writers... (Известие о некоторых русских писателях...; in the original German: Nachricht von einigen russischen Schriftstellern...), published in 1768 in Leipzig by the Neue Bibliothek der schönen Wissenschaften und der freien Künste, ${ }^{1}$ and mentioned in the foreword to Novikov's dictionary:

In 1776 [!], a certain Russian traveller wrote to a Leipzig journal about some Russian writers who had been published in that journal in German, which was a source of great satisfaction. But the message is a rather short one, and is not entirely accurate, while in other places written in emotional tones. This served as inspiration for me to compose the present book. (...) Not in order to criticise the anonymous author. (...) I mentioned his letter not to praise myself; rather, I did it to show how difficult it is to be the first to publish such a work ${ }^{2}$.

[Между прочим в 1766 [!] году некто российский путешественник сообщил в лейпцигский журнал известие о некоторых российских писателях, которое во оном журнале на немецком языке напечатано и принято с великим удовольствием. Но сие известие весьма кратко, а притом инде не весьма справедливо, а в других местах пристрастно написано. Сие самое было мне главным поощрением к составлению сея книги. (...) Не в порицание

\footnotetext{
1 Authorship has most frequently been attributed to Ivan Dmitryevsky, Sergey Domashnyev, and Alexander Volkov. Researchers either name all of the suspected creators, thus outlining the history of scholarship on the subject (see Zdobnov 1955: 109), or indicated one - such as Volkov - as the most likely (see Nikolaev, Kurilov, Grišunin 1980: 36).

2 Here and later on the translations are my own, unless otherwise stated - M.D.
} 
неизвестному писателю (...) упомянул я здесь о его известии и не в похвалу себе; но только для того, чтобы показать, сколь трудно в первый раз издавать такого рода сочинения] (Novikov 1951: 278).

Nikolai Novikov's dictionary, created with a view to filling a gap in the indigenous scholarly literature, existing due to the absence of such publications which could be found for years in other European countries, contained notes about 317 individuals, including 9 women $^{3}$. The entries are arranged in alphabetical order. Their structure is not uniform, depending on the author's knowledge about particular authors: apart from basic biographical information (not always complete), entire works were cited in some places. We can observe this in the entry about Ivan Rudakov, which is almost entirely made of his Poem for "An Attempt at a Historical Dictionary of Russian Writers" (Стихи к "Опыту Исторического Словаря о Российских Писателях") (Rudakov 1951: 346-347). In that poem, a lyrical review praising the work of Nikolai Novikov, we encounter words about 'Russian Sapphons', a label (along with 'a Sapphon of our times') primarily applied to Anna Bunina, also referred to as 'the first professional Russian woman writer' (Sviâsov 1995: 14). Both were employed by the sentimental poet Pyotr Shalikov referring to her in the poem To $A^{*} P^{*} \ldots\left(K^{*} A^{*} \Pi^{*} \ldots\right)$, written in 1808 (see Dąbrowska 2017: 273-278). There is an entry for her in all dictionaries of Russian women writers. In Ivan Rudakov's poem there is also mention made - in the context of the blossoming of science and culture - of Catherine II, about whom, in turn, Nikolai Novikov did not write a separate entry, limiting himself to a courteous mention of her in the author's foreword to the dictionary. Discussion on the reasons behind the absence of an entry devoted to Catherine II, initiated by Grigory Makogonenko (Makogonenko 1951: 177-181) and summarised by Mikhail Lepekhin (Lepehin 1989: 244-245), did not produce an unequivocal answer. It cannot be excluded that Nikolai Novikov sought to demonstrate in that manner his opposition to the empress, using it as a polemical instrument, but perhaps it was simply inappropriate for him to 'reduce' her to the level of the other artists by placing the empress alongside them. In this context it should be recalled that a second impulse leading Nikolai Novikov to begin work on the dictionary - and which, unlike the article in the Leipzig-based journal, he did not mention - was the polemic written by Catherine II in response to the book of the French astronomer and traveller Jean Chappe d'Auteroche, A Journey to Siberia (Voyage en Siberie), published in Paris in 1761 ([Ekaterina II] 1869: 225-463). The ruler took umbrage with critical remarks about Russia made by the foreigner, who presented the country as deficient in culture. It is worth exploring one particular passage from this little-known text in which Catherine II addresses the situation of women in Russia over centuries:

In the past, women were not much more shut up in their homes than they are today. There was no public celebration which they did not attend, no private celebration in which they did not participate. (...) Our ladies were in older times less isolated than the ladies of France were after Francis I took the throne.

3 Anna Wielisheva-Volyntseva, Yekaterina Dashkova, Maria Zubova, Yekaterina Kniazhnina, Aleksandra Rzhevskaya, Nataliya Titova, Yekaterina Urusova, Maria Khrapovitskaya, Yelizaveta Kheraskova. 
[Женщины в старину не были гораздо более заперты в домах, чем теперь. Не было ни одного публичного праздника, на котором они бы не присутствовали, праздника частного, в котором они бы не участвовали. (...) Наши дамы в старину были менее заперты, чем французские дамы при восшествии на престол Франциска I-го] ([Ekaterina II] 1869: 426).

The author of An Attempt at a Historical Dictionary of Russian Writers took as his primary objective keeping alive the memory of indigenous artists, and he succeeded in recording more of them than his predecessor from 1768. The article in the Leipzig periodical contained notes on a mere 42 people.

Nikolai Novikov captured the essence of his general dictionary of writers in one sentence of his foreword:

I have tried to gather the names of all our writers...

[Я старался собирать имена всех наших писателей...] (Novikov 1951: 278).

Later in the foreword, Nikolai Novikov stipulates that his work on native writers is not yet a dictionary in the full sense of that word, but - considering the incompleteness and imprecision of the information therein - is an ersatz dictionary, a preview, an exploratory study in advance of a future dictionary that he was inviting his readers to collaborate on:

In the course of the printing of my book, I have received information about many [writers M.D.]; this alone gives hope that many more of them will be discovered. With this in mind, it remains only for me to request the support of my readers in my work.

[При отпечатании моей книги получил я еще о многих [писательницах - M.D.] известие; а сие самое подает надежду, что и еще многие откроются. В таком случае остается мне просить вспомоществования в моем труде от моих читателей] (Novikov 1951: 278).

For this reason he did use the term 'dictionary' in the title, but rather the descriptive 'an attempt at a dictionary.' The paucity and imprecision of information was particularly acute at the bibliographical level. "We never had so many bibliographers, and there were never so many mistakes, perhaps because in the past there was less bibliographical information," admits Mikhail Dmitryev in a review of a dictionary of Russian women writers published in his times (Dmitriev 1857: 577).

An Attempt at a Historical Dictionary of Russian Writers then became a reference point for those authoring dictionaries of women of the pen. Just as Nikolai Novikov in his foreword invoked Information on Some Russian Writers, published four years prior to his dictionary, those who followed him would invoke his work, which preceded the first Russian dictionary of women writers by over fifty years (the roots of this breed of specialist writers' dictionaries stretch back to the 1820s). And like Nikolai Novikov, the majority of them would implore their readers to send information to make corrections and additions. It should be noted that Stepan Vengerov did the same in his 'general' Critical-Biographical Dictionary of Writers and Scholars... (Kритикобиограбический словарь русских писателей и ученых...) (Vengerov 1889: 13). Ultimately, in Nikolai Novikov's fashion - for a reason already understood - they would also avoid referring to their works as 'dictionaries', adopting the 'safer' labels of 'survey', 'catalogue,' or 'materials.' 
The history of dictionaries of Russian women of the pen traces back to the 1826 Bibliographical Catalogue of Russian Women Writers (Библиографический каталог русским писательницам) by Stepan Russov (1768-1842) ([Russov] 1826; see Dąbrowska 2016a: 46-49). The author - not only a bibliographer, but also poet and historian - was not regarded highly by his contemporaries. "The work is that of one Stepan Russov, a terribly poor writer, active in the literary field since the third decade of the past century," wrote Mikhail Semevsky in the context of his odes in honour of Paul I (Semevskij 1869: 476). A second work is Mikhail Makarov's Materials for the History of Women-Authors (Материаль для истории русских женщинавторов), published in 'episodes' of various lengths in Pyotr Shalikov's "Women's Journal" ("Дамский журнал") at the beginning of the 1830s. (Makarov 1830, 1833, passim). Opinions about Mikhail Makarov (1785-1847), generally recognised as the publisher (along with Sergei Kryukov, Ivan Smirnov and the aforementioned Pyotr Shalikov) of the woman's journal "Review for the Amicable" (“Журнал для милых", 1803) were not favourable: the periodical was considered indecent (see Dąbrowska 2014: 415-425), while in Materials for the History of Women-Authors, as the poet Pyotr Vyazemsky expressed in a letter dated 13 December 1835, the author's tendency "to mix everything up with everything else" was on full display [Vâzemskij 1869: 642]. Opinions were also not very positive of Pyotr Shalikov, one of the most characteristic of the sentimentalists, considered something of a scribbler and epigone of the literary trend represented by "Women's Journal," about which Adam Mickiewicz, in Russia at the time, wrote: "Women's Journal' of the Prince Shalikov, an object of derision and epigrams, nevertheless boasts 300 subscribers, if not more..." (Mickiewicz 1998: 402). In the context of Mikhail Makarov's cooperation with periodicals for women, it should be recalled that the publisher of the first of them ("Модное ежемесячное издание, или Библиотека для дамского туалета", 1779), was Nikolai Novikov. The next to take up work on a dictionary of Russian women writers was Nikolai Golitsyn (1836-1893), a bureaucrat, historian, bibliographer, editor of the newspaper "Warsaw Daily" ("Bapшавский дневник"). His work, initiated in the 1850s and published in 1889, bears the title Bibliographical Dictionary of Russian Women Writers (Библиограбический словарь русских писательнии) (Golicyn 1889). That work on the dictionary began in the middle of the nineteenth century is attested to by the fact that, beginning at that time, Golitsyn printed fragments of it in periodicals: the newspaper "Molva" ("Молва") in 1857 (the previously cited ironic quote by Mikhail Dmitryev was about this particular publication) ([Golicyn 1857, passim]); the journal "Russian Archive" (“Русский архив") in 1865 (under the pseudonym Nikolai Knizhkin) (Golicyn 1865: 1391-1481); shortly after the book was published under his own name in "Warsaw Daile" in 1880 (Golicyn 1880, passim); and in "Journal of the Ministry of National Education” (“Журнал Министерства Народного Просвещения”) in 1888-1889 (Golicyn 1888-1889, passim). This fragment of the history of dictionaries of Russian women writers thus encompasses the years from 1826 to 1889 - unless we also take into account Stepan Ponomaryov's Our Women Writers. A Bibliographical Dictionary of Russian Women Writers (Наши писательницы. Библиограбический словарь русских писательнии), published in 1891 (Ponomarev 1891; see Dąbrowska 2018: 
13-21), a supplement to Nikolai Golitsyn's book, its second part also in the form of a dictionary - the period 1826-1891.

Nikolai Golitsyn was also subjected to critical remarks, which, as his remarks from 1857 indirectly indicate, he had expected from the beginning of his work on the dictionary:

It remains merely for me to express my dismay that my Bibliographical Notes [Библиографические заметки - M.D.] have yet to serve as the pretext for an appropriate comment, or for a proposal of correction, and that I must point out the highly visible errors of my opponents

[Остается мне пожалеть, что мои Библиограбические заметки не подали еще повода ни к одному дельному замечанию или поправке и что я вынужден подмечать и раскрывать слишком неосторожные промахи моих противников] (Golicyn 1857, no. 31: 375).

The charges levelled by Stepan Ponomaryov against Nikolai Golitsyn, which comprised the first, critical-descriptive portion of his work, related primarily to the incompleteness and imprecision of the information contained in the book, blindingly obvious even in passages about the most thoroughly characterised Tsar Catherine II and Yekaterina Dashkova (Ponomariov 1891: 1-2). Catherine II, glossed over, as we know, in Novikov's dictionary, was the subject of a long entry in the work by Makarov. The nineteenth-century authors of dictionaries were no longer subject to the same external conditions that faced the eighteenth-century author; it could even be supposed that they might not have understood them.

A distinguishing feature of the dictionaries of Russian women writers composed in the nineteenth century is that they were created, in a sense, 'before the very eyes' of their readers, and with their active participation, to which they were encouraged directly by the dictionaries' authors, particularly Makarov and Golitsyn at the early stages of their work. As we know, Novikov had invited his readers to collaborate earlier. It was accordingly a frequent practice for the authors of dictionaries to reveal the gaps in their knowledge, and to thank those who provided them with information. Golitsyn did so in 1857:

Here [i.e. Willamova-Lanskaya - M.D.] works are unknown to us. We are only aware that there were two writers in our literature with that name.

[Произведения ее [т.е. Вилламовой-Ланской - M.D.] нам неизвестны. Мы знаем только, что было две писательницы этой фамилии в нашей литературе] (Golicyn 1857, no. 29: 347).

For supplying certain information about M.W. [Maria - M.D.] Sushkova, I would like to express my sincere gratitude to N.W. [Nikolai V. - M.D.] Sushkov.

[За доставление некоторых сведений о М.В. Сушковой приношу искреннюю благодарность Н.В. [Николаю В. - M.D.] Сушкову] (Golicyn 1857, no. 33: 387).

Thus, the application by the authors of the label 'catalogue' or 'materials' to their works would appear justified. They released them to their readers as though guided by the Latin precept "Feci, quod potui, faciant meliora potentes.". Isaak Kaufman even considered 'materials' to be a separate group of bio- and bibliographical treatments

4 "I did what I could; whoever is capable, may he do better." This is a paraphrase of the words spoken by a Roman consul in the act of relinquishing his post to his successor. 
(Kaufman 1955: 319-325), 'embryonic' in comparison with the 'full', 'expanded' dictionary form. In essence, almost the entire nineteenth-century period in the history of dictionaries of Russian women writers can be termed the 'materials' period, a preparatory phase for the actual work - something beyond just the collection and verification of basic information - to be done in that scope. Stepan Russov wrote about this in the foreword and dedication to Bibliographical Catalogue of Russian Women Writers:

I have completed (...) the first part of the obligation; but the second, consisting in the creation of a historical dictionary, I have concluded to be entirely impracticable; among the many difficulties, the mere collection of information requires an endless exchange of letters. This is why, rather than a historical dictionary, I present to you a bibliographical catalogue of Russian women writers, which is not entirely complete. If I succeed in gathering enough biographies, I will not fail to include them in the second, corrected edition of this little book.

[Первую часть поручения (...) я исполнил; но другую, относительно составления исторического словаря нашел совершенно невозможною; кроме других препятствий одно собрание сведений требует переписки бесконечной. По сему вместо исторического словаря подношу вам библиографический каталог Российским писательницам и то не совершенно исправной. Если соберется достаточное количество жизнеописаний, то я в последствии не премину поместить их во втором исправленном издании сей книжки] (Russov 1826: 0) ${ }^{5}$.

The desire to spread knowledge about the literary accomplishments of women, which - primarily because of the paucity and dispersion of sources - had been very limited, is given as a leading reason for setting out to create a dictionary of women writers. Nikolai Golitsyn writes in language similar to Stepan Russov:

Unfortunately, even the mere names of women writers are almost entirely unknown to our readers - of course, apart from the two or three most important. Thus, we feel it will not be unjustified to make the fullest possible compilation of our women poets, storytellers, translators, etc. What materials does Russian bibliography supply for such a work? Only the most miserable, poor, imprecise and misleading. In this material, it is necessary to independently compile the list of authors, to extract the most scant details from old journals: there are no catalogues, dictionaries, or compilation; the bibliography is flying blind. (...) The time has long since come for lovers of our literature to be able to read that chapter in the history of Russian literature!

[К сожалению, писательницы наши почти неизвестны читающей публике, даже по имени - разумеется, кроме двух-трех, главнейших. Поэтому, кажется, не лишним будет сделать возможно полный список нашим женщинам поэтам, романисткам, переводчицам и т.п. Какие-же материалы к такому труду представляет русская библиография? Самые жалкие, скудные, неверные, сбивчивые. Тут, самому должно воссоздавать авторов, выкапливать из старых журналов указания самые скудные: каталогов, словарей, списков нет; библиограф должен идти ощупью. (...) Давно пора бы обратиться любителям нашей словесности к этой стороне истории русской литературы!] (Golicyn 1857, no. 28: 333-334).

The calculations in Nikolai Golitsyn's foreword to the 1889 book tell us that Stepan Russov's 'catalogue' shed light on 97 authors; there were 65 of them named in Makarov's 'materials;' and Nikolai Golitsyn's own dictionary detailed 314 people (in its first edition from 1857), 440 (in the 1865 version), and ultimately 1,285 (in the Bibliographical Dictionary of Russian Women Writers from 1889) (Golicyn 1889: III, IV, VI).

5 Nothing is known about the second edition of the volume. 
The second, dictionary part of Ponomariov's Our Women Writers contained the creative profiles of 419 women, including fourteen writing in foreign languages ${ }^{6}$. Nikolai Golitsyn had previously pointed to the urgent necessity of taking account of that last group of authors:

We haven't the slightest right to exclude from the circle of Russian women writers those few of our ladies who, while being Russian, wrote in French.

[Мы не имеем никакого права исключать из числа Русских писательниц тех немногих наших дам, которые, будучи русскими, писали по-французски] (Golicyn 1857, no. 28: 335) ${ }^{7}$.

In Russov's Bibliographicical Catalogue of Russian Women Writers and Golitsyn's Bibliographical Dictionary of Russian Women Writers, as well as the "dictionary" portion of Ponomaryov's Our Women Writers, the entries were arranged in alphabetical order (by surname, or first name if necessary; in the Nikolai Golitsyn volume, authors whose names are unknown are listed as 'Anonymous'). In Mikhail Makarov's Materials for a History of Russian Women-Authors - the most complicated structure - a chronological structure is applied, which means that he first distinguished periods in the history of literature and assigned particular writers to them, then listed within each section writers from oldest to youngest. Mikhail Makarov employed this structure in the main portion of the 'materials' and in the 'etceteras' to them; the term 'main portion' should be understood as fragments prepared (and published) prior to consultation with readers and (possibly) additional research, while 'etceteras' are amended and additional entries developed in the second phase of work, when the author began to 'drown' in new information and could correct the details he was previously in possession of. Materials for a History of Russian Women-Authors thus has a bipartite structure, including a proposal for a literary historical periodisation. The periods distinguished by Mikhail Makarov in the history of Russian literature bear the names 'the Lomonosov era,' 'the Catherine the Great era,' 'the reign of Paul I', and 'the age of Alexander's.

The extensively discussed 'working version' nature of the dictionaries of women writers, in particular the earliest of them, means that there is no one particular system for the organisation of entries, although it is possible to identify certain elements common to them. To the extent that the knowledge possessed by the author of a dictionary permitted, readers were able to learn the dates of the birth and death of a given writer, her background and family situation, literary contacts and position within the literary community; the main section of a given entry contained an outline of the author's creative history, highlighting her debut and the most important works.

\footnotetext{
6 E.g. Barbara Juliana von Krüdener, of the house of von Vietinghoff, who wrote in French.

7 Writing in French is nothing unusual considering the widespread use of the language in European cultural circles in the eighteenth-nineteenth centuries; see in this context inter alia about Catherine II, Yekaterina Dashkova and Zinaida Volkonskaya (Grečanaâ 2010).

8 Their leading figures include Yekaterina Sumarokova-Kniazhnina (the first period), Yekaterina Dashkova and Yelizaveta Kheraskova (second), Yelizaveta Ogaryova and Maria Orlova (third), Varvara Kniazhnina (fourth). Mikhail Lomonosov, the eminent poet and scholar, lived in the years 1711-1765. The listed rulers reigned in 1762-1796 (Catherine II), 1786-1801 (Paul I) and 1801-1825 (Alexander I).
} 
It was only in the versions of the volume by Nikolai Golitsyn from 1857 and 1865 that timeframes of the material taken into account were clearly indicated; in the former this was the period 1759-1857, while in the latter 1759-1859. The year 1759 was recognized (not only by Nikolai Golitsyn) as the conventional beginning of the literary activity of Russian women, associated with Yekaterina Sumarokova' ${ }^{9}$ Thus, the publication of 1865 can be considered a jubilee volume summarising the 100-year history of that phenomenon in Russia. The titles of the remaining dictionaries mention simply 'Russian women writers.' Their authors strived to be as up-to-date as possible, taking into account their contemporaries and their most recent accomplishments. As for the times prior to 1759 , they are also represented to some extent in the dictionaries: in Stepan Russov's 'Catalogue' there is an entry (indeed, an entry, as despite the title, the volume contains not only a list of women authors but also notes on them) about the daughter of the Grand Prince of Chernigov Vsevolod Yaroslavich, named Anna (Russov 1826: 6).

In the years 1826-1889 (or 1826-1891), another kind of work than dictionaries were being published about women literary figures (E.g. Bilevič 1847a: passim, Bilevič 1847b: passim, Mordovcev 1874). Both the dictionaries of the day as well as works of another nature betray their creators' indecision between treating the output of women as something imbued with unique characteristics, not present in the writings of men, and treating the writings of both sexes as a whole, assessing them by uniform criteria. This is clearly visible in the article The Creativity of Women, written in 1891 by Mikhail Protopopov:

What is woman? We pose this banal yet nevertheless unanswered question for the reason that if woman, as a moral being, is distinguished by some unique characteristics, it is quite clear that those characteristics should make a fundamental mark on her spiritual activity, including literary.

[Что такое женщина? Мы ставим этот избитый и, все-таки, нерешенный вопрос потому, что если женщина, как нравственное существо, отличается какими-нибудь типическими и специальными свойствами, то конечно, эти свойства должны могущественно отражаться и на всякой ее духовной деятельности, в том числе и литературной] (Protopopov 1891a: 102).

The fate of 'female creativity' in our contemporary literature is the same fate that affects male creativity...

[Судьба „женского творчества” в современной литературе нашей - та самая судьба, которая постигла и мужское творчество...] (Protopopov 1891b: 123).

One of the first comprehensive volumes addressing the issue of the position of Russian women in the private and public spheres is A History of the Russian Woman (История русской женщцины), by Serafim Shashkov (1879) (see Šaškov 2011). This example also demonstrates that all of the oldest dictionaries of Russian women writers, as well as other works about women in that country - whether within a synchronous or diachronous framing - were written by the pens of men. And this is not the sole rea-

9 This is the year in which Alexander Sumarokov's “Trudolubivaya pchela” (“Трудолюбивая пчела") was published, containing the poems of his daughter, Yekaterina, sometimes attributed to her father (See Dąbrowska, 2016b: 27-29). 
son why a reading of numerous entries in the dictionaries described above do not allow us to forget about the male portion of the Russian cultural elite: a feature common to the descriptions of women literary figures is information about whose daughter, sister or wife they were, particularly if their fathers, brothers or husbands themselves were involved in literary or publishing activity. Referring in this context to the formula invoked at the beginning of the present paper 'from invisibility to agency', we could say that it was the belief of the first authors of such dictionaries that women owed both their 'visibility' and, frequently, their 'agency' to men. The relations between the sexes in the Russian literary milieu in the period explored here were based on dependency and subordination rather than equality and partnership. On the other hand, Catherine II is deserving of separate mention, as a ruler and author; what is more, a Russian ruler and writer as well initiator of literary and publishing activity, but also of foreign origin. ${ }^{10}$ We see far fewer women than men in history, even though there were far more of them than generally acknowledged, even if many of them were treated as an 'appurtenance' to that history. At the root of the first dictionaries of Russian women writers was the desire to enrich their work with knowledge of the literary historical process, but on the other hand, the collection of information about them in a dedicated dictionary suggested that they constituted a separate entirety in literary history.

If the emergence of general dictionaries of writers should be linked with the Enlightenment drive to achieve comprehensive (encyclopaedical) knowledge of that sphere of human activity, the appearance of specialist dictionaries, which - apart from dictionaries of women of the pen - also include dictionaries of writers representing minorities and religious factions (Old Believers) or authors from particular Russianruled territories, it would also be appropriate to associated it with opposition to the Enlightenment view of literature (and of the world in general) not as a whole, but as an aggregate of distinct phenomena each demanding their own individual treatment. The development of such thinking was not devoid of elements of romantic individualism and regionalism, which supplanted Enlightenment universalism and globalism. This second phase in the development of writers' dictionaries - now specialist rather than general - began in Russia in the 1820s. (see Zdobnov 1955: passim). In both groups of dictionaries of the time, the presence of entries devoted not only to (women) writers defined narrowly as such as active agents within the field of the literary arts, but also those entries dedicated to representatives of the world of culture and science.

In the twentieth century, there was a return to the idea of compiling a dictionary of Russian women writers, particularly since their ranks had significantly expanded, and work was done on this not only in Russia itself (Gorbunov, online) but also abroad (Fajnštejn 1994: 66-67). The most recent such publication is the dictionary compiled by Yelena Tonchu in 2015 (Tonču 2015). Profiles of women of the pen can also be found in general writers' dictionaries (Nikolaev 1996).

The older dictionaries of women writers nevertheless remain of value to historians of literature, as they reflect the condition of knowledge of those from bygone eras and

10 Specifically, Sophie Friederike Auguste zu Anhalt-Zerbst-Dornburg, princess of Anhalt-Zerbst, born in Stettin (Cf. Proskurina 2017). 
the manner in which that knowledge was acquired, while facilitating research in literary studies and scientific information on both diachronic and synchronic planes.

\section{References}

Bałżewska, K., Korczyńska-Partyka, D., Wódkowska, A. (Red.) (2015). Kobiety i historia. Od niewidzialności do sprawczości. Gdańsk: Wydawnictwo Uniwersytetu Gdańskiego.

Bilevič, N., (1847a). Russkie pisatel’nicy XVIII veka. Moskovskij Gorodskoj Listok, (11.04.) No. 78: 311-314; (12.04.) No. 79: 315-316; (14.04.) No. 80: 319-321 [Билевич, Н. (1847a). Русские писательницы XVIII века. Московский Городской Листок, (11.04) № 78: 311-314; (12.04.) № 79: 315-316; (14.04.) № 80: 319-321].

Bilevič, N. (1847b). Russkie pisatel'nicy XIX veka. Moskovskij Gorodskoj Listok, (21.05.) No. 108: 435-438; (22.05.) No. 109: 440-442; (27.05.) No. 113: 451-452; (28.05.) No. 114: 455-457; (3.07.) No. 167: 669-670; (1.08.) No. 168: 673-674; (2.08.) No. 169: 677-678; (5.08.) No. 171: 683-686; (7.08.) No. 172: 688-689; (21.08.) No. 183: 723-733; (25.08.) No. 185: 740-742 [Билевич, Н. (18476). Русские писательницы XIX века. Московский Городской Листок, (21.05.) № 108: 435-438; (22.05.) № 109: 440-442; (27.05.) № 113: 451-452; (28.05.) № 114: 455-457; (3.07.) № 167: 669-670; (1.08.) № 168: 673-674; (2.08.) № 169: 677-678; (5.08.) № 171: 683-686; (7.08.) № 172: 688-689; (21.08.) № 183: 723-733; (25.08.) № 185: 740-742].

Dąbrowska, M. (2014). W kręgu rosyjskich czasopism dla kobiet początku XIX wieku (spór o „Żurnat dla mitych”). W: Laszczak, W. et al. (Red.). Między tradycją a nowoczesnościq. Tożsamość kobiety $w$ przestrzeni domu, $w$ historii, kulturze i na drogach emancypacji. Opole: Wydawnictwo Uniwersytetu Opolskiego: 415-425.

Dąbrowska, M. (2016a). „Jesteśmy wdzięczni miłej autorce...”. O kobietach pisarkach w rosyjskich czasopismach dla kobiet (koniec XVIII - pierwsza połowa XIX wieku). W: Chodurska, H., Kotkiewicz, A. (Red.). Tradycja i nowoczesność. Język i literatura Słowian Wschodnich. Kraków: Wydawnictwo Naukowe Uniwersytetu Pedagogicznego: 41-52.

Dąbrowska, M. (2016b). Rodziny literackie w Rosji czasów Oświecenia (trzy przykłady). Rusycystyczne Studia Literaturoznawcze, 26: 25-36.

Dąbrowska, M. (2017). Kobiety w kulturze rosyjskiej na początku XIX wieku (na podstawie czasopism Piotra Szalikowa). W: Głowacka-Penczyńska, A., Grysińska-Jarmuła, K., Opioła-Cegiełka, M. (Red.). Kądziel - kołyska - łoże. Atrybuty kobiecości na przestrzeni dziejów. Bydgoszcz: Wydawnictwo Uniwersytetu Kazimierza Wielkiego: 267-282.

Dąbrowska, M. (2018). O słowniku pisarek rosyjskich Nikolaja Golicyna i odpowiedzi na niego Stiepana Ponomariowa. W: Scripta Humana. T. 11: Kobiety-pisarki, kobiety-bohaterki. Bielniak, N., Urban-Podolan, A. (Red.). Zielona Góra: Uniwersytet Zielonogórski: 13-21.

Dmitriev, M. (1857). Bibliografičeskie zamečaniâ. Moskovskie vedomosti, (29.10) No. 130: 577 [Дмитриев, М. (1857). Библиографические замечания. Московские ведомости, (29.10.) № 130: 577].

Ekaterina II (1869). Antidot (protivoâdie). Polemičeskoe sočinenie Gosudaryni imperatricy Ekateriny Vtoroj. Perevod s francuzskogo podlinnika. V: Osmnadcatyj vek. Istoričeskij sbornik, izdavaemyj Petrom Bartenevym (izdatelem „Russkogo arhiva”). Kn. 4. Moskva: 225-463 [Екатерина II (1869). Антидот (противоядие). Полемическое сочинение Государыни императрицы Екатерины Второй. Перевод с франиузского подлинника. В: Осмнадиатьй век. Исторический сборник, издаваемый Петром Бартеневым (издателем „Русского архива”). Кн. 4. Москва: 225-463].

Fajnštejn, M.Š. (1994). O rabote po sostavleniû bio-bibliografičeskogo slovarâ 'Russkie pisatel'nicy XVIII veka. V: Tiškin, G.A. (Red.). Rossijskie žensisiny i evropejskaâ kul'tura. Tezisy dokladov II naučnoj konferencji. Sankt-Peterburg: Sankt-Peterburgskoe filosofskoe obŝestvo: 66-67 
[Файнштейн, М.Ш. (1994). О работе по составлению био-библиографического словаря „Русские писательницы XVIII века”. В: Тишкин, Г.А. (Ред.). Российские женщины и европейская культура. Тезисы докладов II научной конференции. Санкт-Петербург: СанктПетербургское философское общество: 66-67].

Głowiński, M. (2010). Słownik. W: Głowiński, M., Kostkiewiczowa, T., Okopień-Sławińska, A., Sławiński, J. Słownik terminów literackich. Wrocław: Ossolineum: 513.

Goik, M. (2010). Kobiety w literaturze. Bielsko-Biała: Wydawnictwo Szkolne PWN.

Golicyn, N.N. (1857). Spisok russkim pisatel'nicam (1759-1857). Molva, (19.10.) No. 28: 333-336; (26.10.) No. 19: 346-348; (19.10.) No. 28: 333-336; (2.11.) No. 30: 354-356; (9.11.) No. 31: 371-375; (23.11.) No. 33: 385-387; (30.11.) No. 34: 393-395; (7.12.) No. 35: 400-403 [Голицын, Н.Н.] (1857). Список русским писательницам (1759-1857). Молва, (19.10.) №. 28: 333-336; (26.10.) № 19: 346-348; (19.10.) № 28: 333-336; (2.11.) № 30: 354-356; (9.11.) № 31: 371-375; (23.11.) № 33: 385-387; (30.11.) № 34: 393-395; (7.12.) № 35: 400-403].

Golicyn, N.N. [Knižkin, N.] (1865). Slovar' russkih pisatel'nic. 1759-1859. Russkij arhiv, No 12: 13911481 [Голицын, Н.Н. [Книжкин, Н.] (1865). Словарь русских писательниц. 1759-1859. Рycский архив, № 12: 1391-1481].

Golicyn, N.N. (1880). Slovar' russkih pisatel'nic. Varšavskij dnevnik, No. 176: 1-3; No. 178: 1-3; No. 180: 1-3; No. 182-186: 1-3; No. 188-189: 1-3; No. 194: 1-3; No. 196-198: 1-3; No. 202: 1-3; No. 209-212: 1-3 [Голицын, Н.Н. (1880). Словарь русских писательниц. Варщавский дневник, № 176: 1-3; № 178: 1-3; № 180: 1-3; № 182-186: 1-3; № 188-189: 1-3; № 194: 1-3; № 196-198: 1-3; № 202: 1-3; № 209-212: 1-3].

Golicyn, N.N. (1888, 1889). Bibliografičeskij slovar' russkih pisatel'nic. Žurnal Ministerstva Narodnogo Prosveŝeniâ, 1888: avgust: 1-32; sentâbr': 33-64; oktâbr’: 65-96 noâbr': 97-160; dekabr': 161-176; 1889: ânvar': 177-224; mart: 225-288; maj: 288-290 [Голицын Н.Н. (1888, 1889). Библиографический словарь русских писательниц. Журнал Министерства Народного Просвещзения, 1888: август: 1-32; сентябрь: 33-64; октябрь: 65-96; ноябрь: 97-160; декабрь: 161-176; 1889: январь: 177-224; март: 225-288; май: 288-290].

Golicyn, N.N. (1889). Bibliografičeskij slovar' russkih pisatel’nic. Sankt-Peterburg: tip. V.S. Balaševa [Голицын, Н.Н. (1889). Библиографический словарь русских писательниц. СанктПетербург: тип. В.С. Балашева].

Gorbunov, Û.A. Pisatel'nicy Rossii. Materialy dlâ biobibliografičeskogo slovarâ. (Online) http://book. uraic.ru/elib/authors/gorbunov/sl-18.htm (dostup 1.11.2018) [Горбунов, Ю.А. Писательницьь России. Материаль для биобиблиографического словаря. (Online) http://book.uraic.ru/elib/ authors/gorbunov/sl-18.htm (доступ 1.11.2018)].

Grečanaâ, E.P. (2010). Kogda Rossiâ govorila po-francuzski: russkaâ literatura na francuzskom âzyke (XVIII - pervaâ polovina XIX veka). Moskva: IMLI RAN [Гречаная, Е.П. (2010). Когда Россия говорила по-французски: русская титература на французском языке (ХVIII - первая потовина ХІХ века). Москва: ИМЛИ РАН].

Kaufman, I.M. (1955). Russkie biografičeskie i biobibliografičeskie slovari. Moskva: Goskul'tprosvetizdat [Кауфман, И.М. (1955). Русские биографические и биобиблиографические словари. Москва: Госкультпросветиздат].

Lepehin, M.P. (1989). “Opyt istoričeskogo slovarâ o rossijskih pisatelâh” N.I. Novikova. (Nekotorye problemy izučeniâ). XVIII vek, No 16: Itogi i problemy izučeniâ russkoj literatury XVIII veka. Pančenko, A.M. (Red.). Leningrad: Izdatel'stvo AN SSSR: 234-250 [Лепехин, М.П. (1989). “Опыт исторического словаря о российских писателях" Н.И. Новикова. (Некоторые проблемы изучения). XVIII век, № 16: Итоги и проблемы изучения русской литературы XVIII века. Панченко, А.М. (Ред.). Ленинград: Издательство АН СССР: 234-250]. 
Levin, G.L., Teplickaâ, A.V. (2015). Ot sostavitelej. V: Levin, G.L., Teplickaâ A.V. (Red.). Otečestvennye bibliografy i bibliografovedy. Ukazatel' dokumental'nyh istočnikov iliteratury o žizni i deâtel'nosti 1917-2014. Moskva: Paškov dom: 5-7 [Левин, Г.Л., Теплицкая, А.В. (2015). Om cocmaвumeлей. В: Левин, Г.Л., Теплицкая, А.В. (Ред.). Отечественные библиограбы и библиограбоведы. Указатель документальных источников и литературы о жизни и деятельности 1917-2014. Москва: Пашков дом: 5-7].

Makarov, M. (1830, 1833). Materialy dlâ istorii russkih ženŝin-avtorov. Damskij žurnal. 1830, Č. 29, No. 1 , s. $1-5$, No. 2 , s. 17-23, No. 3, s. 33-35, No. 7, s. 97-102, No. 10, s. 145-151, No. 13, s. $193-$ 198; Č. 30 , No. 15 , s. 17-20, No. 16, s. 32-39, No. 17, s. 49-58, No. 18, s. 65-76, No. 19, s. 81-85, No. 21 , s. $113-121$, No. 25 , s. $177-185$; Č. 31 , No. 27 , s. $1-8$; Č. 31 , No. 29 , s. $33-44$, No. 30 , s. 49-55, No. 39, s. 193-201; Č. 32, No. 51-52, s. 113-120; 1833, Č. 44, No. 51-52, s. 145-150 [Макаров, М.] $(1830,1833)$. Материалы для истории русских женщин-авторов. Дамский журнал. 1830, Ч. 29, № 1, с. 1-5, № 2, с. 17-23, № 3, с. 33-35, № 7, с. 97-102, № 10, с. 145-151, № 13, c. 193-198; Ч. 30, № 15, c. 17-20, № 16, c. 32-39, № 17, c. 49-58, № 18, с. 65-76, № 19, c. 81-85, № 21, c. 113-121, № 25, c. 177-185; Ч. 31, № 27, c. 1-8; Ч. 31, № 29, c. 33-44, № 30, c. 49-55, № 39, c. 193-201; Ч. 32, № 51-52, c. 113-120; 1833, Ч. 44, № 51-52, c. 145-150].

Makogonenko, G.P. (1951). Nikolaj Novikov i russkoe prosveŝenie XVIII veka. Moskva - Leningrad: Gosudarstvennoe izdatel'stvo hudožestvennoj literatury [Макогоненко, Г.П. (1951). Николай Новиков и русское Просвещение XVIII века. Москва-Ленинград: Государственное издательство художественной литературы].

Martynov, I.F. (1968). “Opyt istoričeskogo slovarâ o rossijskih pisatelâh” N.I. Novikova i literaturnaâ polemika 60-70-h godov XVIII veka. Russkaâ literatura, No. 3: 184-191 [Мартынов, И.Ф. (1968). “Опыт исторического словаря о российских писателях” Н.И. Новикова и литературная полемика 60-70-х годов XVIII века. Русская литература, № 3: 184-191].

Mickiewicz, A. (1998). Dzieła. T. 14: Listy. Cz. 1: 1815-1829). Warszawa: Instytut Badań Literackich Polskiej Akademii Nauk.

Mordovcev, D. (1874). Russkie ženŝiny novogo vremeni. Biografičeskie očerki iz russkoj istorii. Т. 2: Žensiny vtoroj poloviny vosemnadcotogo veka. Sankt-Peterburg [Мордовцев, Д. (1874). Русские женщины нового времени. Биографические очерки из русской истории. Т. 2: Женщины второй половины восемнадиатого века. Санкт-Петербург].

Nikolaev, P.A., Kurilov, A.S., Grišunin, A.L. (1980). Istoriâ russkogo literaturovedeniâ. Moskva: Vysšaâ škola [Николаев П.А., Курилов, А.С., Гришунин, А.Л. (1980). История русского литературоведения. Москва: Высшая школа].

Nikolaev, P.A. (Red.) (1996). Russkie pisateli. XIX vek. Biobibliografičeskij slovar'. T. 1-2. Moskva: Prosveŝenie. Učebnaâ literatura [Николаев, П.А. (Ред.) (1996). Русские писатели. ХІХ век. Биобиблиографический словарь. Т. 1-2. Москва: Просвещение. Учебная литература].

Novikov, N.I. (1951). Opyt istoričeskogo slovarâ o rossijskih pisatelâh. Iz raznyh pečatnyh i rukopisnyh knig soobŝennyh izvestij i slovesnyh predanij sobral Nikolaj Novikov. V: Novikov, N.I. Izbrannye sočineniâ. Ed. by G.P. Makogonenko. Moskva-Lenigrad: GIHL: 270-280. [Новиков, Н.И. (1951). Опыт исторического словаря о российских писателях. Из разных печатных и рукописных книг сообщенных известий и словесных преданий собрал Николай Новиков. В: Новиков, Н.И. Избранные сочинения. Ред. Г.П. Макогоненко. Москва-Ленинград: ГИХЛ: 270-280].

Ponomarev, S.I. (1891). Naši pisatel'nicy. Bibliografičeskij slovar' russkih pisatel'nic, knâzâ N.N. Golicyna. SРВ. 1889, VI і 308. Sankt-Peterburg [Пономарев, С.И. (1891). Наши писательницы. Библиографический словарь русских писательнии, князя Н.Н. Голицына. СПб. 1889, VI и 308. Санкт-Петербург]. 
Proskurina, V. (2017). Imperiâ pera Ekateriny II. Literatura kak politika. Moskva: Novoe Literaturnoe Obozrenie [Проскурина, В. (2017). Империя пера Екатерины II. Литература как политика. Москва: Новое Литературное Обозрение].

Protopopov, M.A. (1891a). Ženskoe tvorčestvo. Russkaâ Mysl', No. 1: 98-112 [Протопопов, М.A. (1891а). Женское творчество. Русская мысль, № 1: 98-112].

Protopopov, M.A. (1891b). Ženskoe tvorčestvo. Statâ tret’â i poslednââ. G-ži Smirnova i Ol'ga Šapir. Zaklûčenie. Russkaâ Mysl', No. 4: 123-141 [Протопопов, M.A. (1891b). Женское творчество. Статья третья и последняя. Г-жи Смирнова и Ольга Шапир. Заключение. Русская мысль, № 4: 123-141].

Rudakov, I. (1951). Stihi k “Opytu istoričeskogo slovarâ o rossijskih pisatelâh". V: Novikov, N.I. Izbrannye sočineniâ. Ed. by G.P. Makogonenko. Moskva-Leningrad: GIHL: 346-347 [Рудаков, И. (1951). Стихи к “Опыту исторического словаря о российских писателях". В: Новиков, Н.И. Избранные сочинения. Ред. Г.П. Макогоненко. Москва - Ленинград: ГИХЛ: 346-347].

Russov, S.V. (1826). Bibliografičeskij katalog rossijskim pisatel'nicam. Sankt-Peterburg: tip. Med. dep. M-va vn. del [Руссов, С.В. (1826). Библиографический каталог российским писательницам. Санкт-Петербург: тип. Мед. деп. М-ва вн. дел].

Semevskij, M. (1869). Oda Imperatoru Pavlu I-mu. 6 noâbrâ 1797 goda. V: Osmnadcatyj vek. Istoričeskij sbornik, izdavaemyj Petrom Bartenevym (izdatelem „Russkogo arhiva”). Kn. 4. Moskva: 476-478 [Семевский, М. (1869). Ода Императору Павлу І-му. 6 ноября 1797 года. В: Осмнадиатый век. Исторический сборник, издаваемый Петром Бартеневым (издателем „Русского архива"). Кн. 4. Москва: 476-478].

Sławiński, J. (2010). Synteza historycznoliteracka. W: Głowiński, M., Kostkiewiczowa, T., Okopień-Sławińska, A. Słownik terminów literackich. Wrocław: Ossolineum: 553.

Smolarczyk-Rostropowicz, J. (1990). Kallimachos. W: Świderkówna, A. (Red.). Słownik pisarzy antycznych. Warszawa: Wiedza Powszechna: 266.

Sviâsov, E. (1995). Safo i „ženskaâ poèziâ" konca XVIII - načala XIX vekov. V: Fajnštejn M.Š. (Red.). Russkie pisatel'nicy $v$ literaturnom processe $v$ konce XVIII - pervoj treti XX vv. Sbornik naučnyh statej. T. 2. Wilhelmshorst: Verlag F.K. Gopfer: 3-16 [Свиясов, Е. (1995). Сабо и „женская поэзия" конца XVIII - начала XIX веков. В: Файнштейн, М.Ш. (Ред.). Русские писательницы в титературном процессе в конце XVIII - первой трети XX вв. Сборник научных статей. T. 2. Wilhelmshorst: Verlag F.K. Gopfer: 3-16].

Šaškov, S.S. (2011). Istoriâ russkoj žensininy. Moskva: Librokom [Шашков, С.С. (2011). История русской женщины. Москва: Либроком].

Tonču, E.A. (2015). Žensinina i literatura. T. 1-2. Moskva: Izdatel'skij Dom TONČU [Тончy, E.A. (2015). Женщина и литература. Т. 1-2. Москва: Издательский Дом ТОНЧУ].

Vâzemskij, P.A. (1869). Pis’ma k I.I. Dmitrievu. Russkij arhiv, No. 1: 642 [Вяземский, П.А. (1869). Письма к И. И. Дмитриеву. Русский архив, № 1: 642].

Vengerov, S.A. (1889). Kritiko-biografičeskij slovar' russkih pisatelej i učenyh (ot načala russkoj obrazovannosti do naših dnej). T. 1. Sankt-Peterburg: Semenovskaâ tipo-litogr.(I. Efrona) [Венгеров, С.А. (1889). Критико-биографический словарь русских писателей и ученых (от начала русской образованности до наших дней). Т. 1. Санкт-Петербург: Семеновская типо-литогр. (И. Ефрона)].

Zdobnov, N. (1955). Istoriâ russkoj bibliografii do načala XX veka. Moskva: Gos. izd-vo kul'turnoprosvet. lit. [Здобнов, Н. (1955). История русской библиограбии до начала ХХ века. Москва: Гос. изд-во культурно-просвет. лит.].

Competing interests: The author declares that she has no competing interests. 